\title{
Moderate Muslims' Views on Multicultural Education, Freedom of Expression, and Social Media Hate Speech: An Empirical Study in West Java Indonesia
}

\author{
Husni \\ Institut Agama Islam Darussalam (IAID) Ciamis, Jawa Barat \\ Email: husni1967@yahoo.co.id \\ Received: January 22, 2019 | Accepted: July 5, 2019
}

\begin{abstract}
West Java Province is often assumed to be the center of radical Islam growth in Indonesia, especially since the reform era. The truth and validity of this presumption need to be proven empirically. Indeed, in this province, there are a number of hardline Islamic organizations with the members spread in almost all corners of West Java. The Wahid Foundation survey from 2010 to 2017 always put this province with the highest incidence of religious-based violence. Therefore, the study on the views of moderate Muslim leaders on freedom of expression, hate speech on social media, and the importance of multicultural education are deemed to be very necessary. The qualitative research data on 73 moderate Muslim figures in West Java was collected by direct interviews, via email, social media, telephone calls, and from their opinions in various media. The results showed that moderate Muslim leaders in West Java uphold and respect freedom of expression as one of the basic human rights, but they refuse if this right is misused to spread hate speech. They also agree with the importance of rules and law enforcement to overcome the problem of spreading hate speech, but according to them, the legal aspect is not the only approach. They view multicultural education as a long-term strategy to build a mature democratic society with high ethical standards.
\end{abstract}

\begin{abstract}
Abstrak
Provinsi Jawa Barat kerap disinyalir sebagai pusat pertumbuhan Islam radikal di Indonesia, khususnya sejak era reformasi. Sinyalemen ini memang perlu dibuktikan kebenaran dan kesahihannya secara empirik. Memang, di provinsi ini terdapat sejumlah organisasi Islam garis keras yang keanggotaannya tersebar hampir di semua pelosok Jawa Barat. Survei The Wahid Foundation sejak tahun 2010 sampai tahun 2017 selalu menempatkan provinsi ini sebagai yang tertinggi tingkat kejadian kekerasan berbasis agama. Maka, penelitian tentang pandangan tokoh Muslim moderat tentang kebebasan berekspresi, ujaran kebencian di media sosial, dan pentingnya pendidikan multikultural diyakini sangat penting. Data penelitian kualitatif terhadap 73 tokoh Muslim moderat di Jawa Barat ini dikumpulkan dengan wawancara langsung, melalui email, media sosial, panggilan telepon, serta opini mereka di berbagai media. Hasil penelitian menunjukkan tokoh Muslim moderat di Jawa Barat menjunjung tinggi dan menghormati kebebasan berekspresi sebagai salah satu hak dasar manusia, tetapi mereka


menolak apabila hak asasi tersebut disalahgunakan untuk menyebarkan ujaran kebencian. Mereka juga berpandangan pentingnya aturan dan penegakkan hukum untuk mengatasi problem penyebaran ujaran kebencian, namun menurut mereka, aspek hukum bukan satusatunya pendekatan. Mereka memandang pendidikan multikultural sebagai strategi jangka panjang untuk membangun masyarakat yang matang berdemokrasi serta memiliki standar etika tinggi.

\section{Keywords}

Moderate Muslim, freedom of expression, social media, hate speech, multicultural education

\section{Introduction}

In relation to the hate speech and freedom of expression, the opinions of the moderate Muslims are usually less loud than the voices of members of extremist and radical groups. The study conducted by Mathew et.al. about the spread of online hate speech on social media showed that the profile of social media users who often spread hate speech is far more influential, more popular, and more cohesive than the profile of social media users who do not spread hate speech (Mathew, Dutt, Goyal, \& Mukherjee, 2018). Mathew's study of 341 thousand users and 21 million posts on social media illustrated the dynamics of diffusion of social media users which are full of hatred, while at the same time broadening the understanding horizon about the online spread of hate.

If the trend consistently develops, the future of social media will be increasingly tainted by hateful content that can threaten the existence of freedom of expression itself. Even at the present, the spread of hate speech on social media and other internet media is very worrying, not only because the number of internet users is constantly increasing from time to time, but it is also because a number of issues that encourage the growth of hate speech are also getting stronger, especially the issue of religion, race, ethnicity, LGBT, immigrants and foreign workers, and politics. The concern about the spread of hate speech is also associated with violence in the real world because the words of hate online also correlate with offline violence. Some of the history of violence and warfare was triggered by, among other things, hate speech (Shaw, 2011), including its use to promote slavery in the American Colonial era, wars in Bosnia-Herzegovina, the development of Nazi ideology, Rohingya Muslim genocide in Myanmar, and a number of attacks on places of worship in various countries. Even if it does not cause direct violence in the real world, the utterance of hate on social media can be a precondition for the occurrence of hate crimes. 
The spread of hate speech on social media that cause violence in the real world also often occurs in Indonesia (International NGO Forum on Indonesian Development (INFID), 2019), including in one of its provinces, West Java. This province with the largest population in Indonesia is a fertile ground for the growth and spread of hate speech on social media. Hate speeches on social media that are related to acts of violence in a number of places in West Java are mostly triggered by issues of religion and belief. These two main issues often trigger violence in some regions of this province. A number of surveys conducted by the Wahid Foundation (formerly known as The Wahid Institute) from year to year always show the high number of religious-based violence cases in this province. From 2010 to 2016, religiousbased violence in West Java always ranked first compared to other provinces in Indonesia (The Wahid Foundation, 2017; The Wahid Institute, 2010, 2011, 2012, 2013, 2014, 2015, 2016). In 2017, religious-based violence in West Java was ranked second after the DKI Jakarta (The Wahid Foundation, 2017), but the incidence still remained very high. These data illustrate the high dynamics of religious life in this province. The phenomenon of the high level of religious-based violence in West Java is also shown by the proliferation of "hardline" Islamic organizations, such as the Islamic Defenders Front (Front Pembela Islam/FPI), Hizbut Tahrir Indonesia (HTI) which then was disbanded, the Indonesian Ulama Forum (Forum Ulama Umat Indonesia/FUUI), United Islamic Community Forum (Forum Umat Islam Bersatu/FUIB), and Anti-Shi'a National Alliance (Aliansi Nasional Anti Syiah/ANNAS). These organizations are not all centered in West Java and some have national-scale movements, such as FPI and HTI, but the existence and activities of these groups are widely known by the community of this province.

Because the characters of the movements of these organizations that are "militant", "frontal", "hardline" and do not hesitate to attack other groups verbally and physically, it is not surprising that their movements and activities often collide with other groups. They often oppose and target minority groups such as Ahmadiyah followers, Syiah, liberal communities (Woodward, 2014), intellectuals, and moderate figures, and other minority groups. The existence of these extreme organizations does not really lie in the strength of the number of its members, but it is supported by at least two conditions that enable these groups to be strong. The two conditions are: First, the dynamics of national political power which in the past few years were dominated by the power of the secular-nationalist party. In such conditions, the party that disapproves or "opposes" the ruler is believed to be an honorable, commendable, and "heroic" one. Secondly, political dynamics at the global level where political parties and 
right-wing figures get significant votes from voters (Eatwell, 2000; Kehrberg, 2007), even Donald Trump, the right-wing figure from Republican won the presidential seat in the United States Election. The increase in the vote acquisition on a number of right-wing parties and figures in Europe and America is in line with the increasing populism belief which is anti-immigrant (Betz, 2003; Ignazi, 2009), xenophobic (Inglehart \& Norris, 2016), and antimulticulturalism. These populist right-wing parties in Europe and America were able to exploit the flood of immigrants from the Middle East and Africa in such a way that turning this humanitarian issue into a scary issue because it was linked to the issue of Western Islamization, threats of immigrants dominating the employment, and threats to the Western values. As a result, not a few people in a number of European and American countries-especially young people who are still looking for self-identity and still have to compete for work-view immigrants as a real threat.

The socio-political dynamics in various parts of the world that tend to increasingly corner Muslims is what strengthens the growth of Islamic radical groups in various countries, including Indonesia. In their own country, these radical-militant groups often identify themselves as anti-Western and skeptical of everything that is Western, including democracy, freedom of thought, freedom of expression and expressing opinions, freedom of religion, human rights, gender equality, and others. As a result, the community who actively mention these issues are also often the victims of their verbal abuse. Even moderate Muslim communities often become victims of their verbal abuse. ${ }^{2}$

Social media are seen as a more effective platform in conveying messages, sharing information, disseminating ideas, notions and thoughts, is a new weapon that is truly utilized by radical-militant groups in various countries, including Indonesia. In the name of freedom of speech and expression-to tackle the issues that these groups have not really liked so far ${ }^{b}$, various forms of hate-speech they create, share, and spread through social media to provoke, spread hatred, create hostility, intimidate, scare, and threaten other groups who do not agree with them.

In Indonesia, social media hate-speech often intertwines with political and religious issues. The events of political events, especially general elections, are the momentum of the proliferation of hate speeches on social media. The

\footnotetext{
a Dedi Mulyadi, one of the moderate Muslim figures in West Java had been a victim of verbal abuse, accused of heresy, polytheism and infidels, while serving as Regent of Purwakarta and making a more impartial policy towards the values of Sundanese culture. See, https://bit.ly/2HSJptS, accessed on March 12, 2019.

${ }^{b}$ Before the era of social media was born and developed, militants were the group that most strongly opposed the idea of freedom of speech and expression. They often intimidate and threaten other people or communities who are thought to have liberal thoughts and expressions in the religious and artistic fields.
} 
topic of social media hate-speeches is the international issue which is not of Indonesia's style. Internationally, the proliferation of hate speech has much to do with the issue of economic migrants, refugees, increased extremism and xenophobia (Mesa, 2016). In Indonesia, based on the results of a study by Husin et al. concluded that the increase in hate-speech is caused more by the psychological condition of individuals, which are psychology, environmental factors, amenities, facilities and technological advances, lack of social control, ignorance of the community, and the interests of society (Husin, Febriyani, \& Sunarto, 2018). However, the issue that is seen as the most powerful influence on the rise of hate speech is the increasing religious extremism (Matteo, 2017).

The increase of hate speeches on social media confronts the most fundamental human rights issues, the freedom of speech and expression which is a very interesting topic not only for lawmakers and social activists, but also for the researchers. On the one hand, freedom of speech and expression requires the open, tolerant social spaces that respect racial, ethnic and religious differences supported by multicultural awareness of its citizens; on the other hand, that social spaces, especially social media, becomes the main trigger of the proliferation of hate speeches, especially through social media (Husni, 2016).

That dilemma of social spaces is what becomes the background of this study. Using the moderate Muslim community as the object, this study aimed to find out the views of the moderate Muslim community in West Java about freedom of expression and hate speech on social media and the role of multicultural education in dealing with that dilemma. Freedom of expression is a human right protected and recognized in various national and international rules. At the international level, there are the Universal Declaration of Human Rights (UDHR) and the International Covenant on Civil and Political Rights (ICCPR) which guarantee the freedom of expression. This freedom is protected by UDHR, especially on article 19, "Everyone has the right to freedom of opinion and expression; this right includes freedom to hold opinions without interference and to seek, receive and impart information and ideas through any media and regardless of frontiers." The ICCPR Rules on this freedom are also found in article 19 paragraph (1) and (2), "(1) Everyone shall have the right to hold opinions without interference. (2) Everyone shall have the right to freedom of expression; this right shall include freedom to seek, receive and impart information and ideas of all kinds, regardless of

\footnotetext{
a In Indonesia, the UDHR had been ratified through the Decree of the People's Consultative Assembly of the Republic of Indonesia Number XVII/MPR/1998 on Human Rights.
} 
frontiers, either orally, in writing or in print, in the form of art, or through any other media of his choice."

At the national level, the guarantees of freedom of expression are found in the 1945 Constitution, MPR Decree, and a number of laws. In the 1945 Constitution that has undergone several amendments, freedom of expression is stipulated in Article 28 which protects the citizens' freedom of association, assembles and gives opinions. Freedom of expression is also guaranteed through the Decree of the People's Consultative Assembly (Majelis Permusyawaratan Rakyat/MPR) of the Republic of Indonesia Number XVII/MPR/1998 on Human Rights. Through this MPR Decree, the Indonesian nation has ratified UDHR. In addition, the guarantee of freedom of expression by law is contained in Law Number 39 of 1999 on Human Rights and Law Number 12 of 2005 on the Ratification of International Covenant on Civil and Political Rights. Other legislative laws governing this freedom are Law Number 40 of 1999 on Press, Law Number 32 of 2002 on Broadcasting, Law Number 11 of 2008 on Information and Electronic Transactions, and Law Number 33 of 2009 on Films.

According to the UDHR and ICCPR, freedom of expression in principle includes the types of freedom without restrictions (to hold opinions without interference). However, Indonesia is not absolutist (Pember, 2001) that gives absolute freedom to its citizens. In addition, freedom of expression is included in the derogable human rights (Svensson-McCarthy, 1998), so that the state can limit it through statutory regulations. This is different from the nonderogable human rights (Weissbrodt \& de la Vega, 2007), where the state cannot reduce its fulfillment even in an emergency. These human rights with non-derogable type include (i) rights to life; (ii) rights to be free from torture; (iii) rights to be free from slavery; (iv) rights to be free from imprisonment for inability to fulfill a contractual obligation (debt); (v) rights to be free from retroactive criminal law; (vi) Rights to recognition before the law; and (vii) Rights in the freedom of thought, conscience and religion

In accordance with the UDHR and ICCPR, the state is permitted to restrict its citizens' freedom of expression as long as they are carried out with three conditions: restrictions must be regulated in the law, must be in accordance with one of the objectives stated in the text, and such restrictions are required. ${ }^{\mathrm{b}}$ In Indonesia, restrictions on freedom of expression are regulated

\footnotetext{
a Indonesia ratified the ICCPR through Law Number 12 of 2005 concerning Ratification of the International Covenant on Civil and Political Rights.

${ }^{\text {b Article }} 29$ paragraph (2) of the UDHR states conditions that allow restrictions on expression, which is "In the exercise of his rights and freedoms, everyone shall be subject only to such limitations as are determined by law solely for the purpose of securing due recognition and respect for the rights and freedoms of others and of meeting the just requirements of morality, public order and the general welfare
} 
in the constitution, especially Article 28J paragraph (1) and (2). The regulation is also carried out by Law No. 39 of 1999 concerning Human Rights, in Articles 70 and 73. restrictions on the implementation of freedom of expression in the ICCPR is needed to ensure the realization of public order, public health, public morals, national security and public security, rights and the freedom of each people, the rights or reputation of each people, the interests of the people's personal lives relating to restrictions on the press and the public on the court. In the 1945 Constitution and Law Number 39 of 1999, restrictions are needed to guarantee recognition and respect for the rights of the people's freedom, morals, religious values, security, public order, morality and the interests of the nation.

The regulation of restrictions on freedom of expression by this law is deemed necessary to prevent what John Satuart Mill called "mischievous" expression or action (Mill, 1865) which is delivered in verbal, written, image, audio, video, or through various media channels (print, electronic, internet, social media, etc.), which are then also known as "hate-speech". Academically, hate speech is not easily defined. However, basically, hate speech can be interpreted as a statement-oral or written —intended to humble, harass, hurt, berate, revile, offend, insult, humiliate another person or group of people (Hauptfleisch, 1993). Nicholas Wolfson limited it as an offensive statement directed at minorities (Wolfson, 1997). For him, hate speech can be subtle and vulgar. In a subtle format, hate speech can be in the form of books, films, and television shows that demean minorities, while a vulgar example is a racist and sexist nickname. Included in the vulgar hate speeches are any statements that threaten and intimidate, spread hatred, incite, complain, and create hostility (Erjavec \& Kovačič, 2012) in the community based on religion, ethnicity, race, tribes, color, gender, sexual orientation, age, physical or mental disability, etc (Frable, 1997).

Susan Brison interpreted hate speech as slander delivered face-to-face using hostile words to create a hostile and frightening environment (Brison, 1998). In Rae Langton's view, hate speech is about expressing, inciting, and spreading hatred (Langton, 1993). The Council of Europe's Committee of Ministers stated that the terminology of hate speech must be understood as encompassing all forms of expression that spread, incite, promote or justify racial hatred, xenophobia, anti-Semitism or other forms of hate based on intolerance, including intolerance expressed through nationalism and ethnocentrism aggressiveness, discrimination and hostility towards minorities,

in a democratic society". In ICCPR article 19 paragraph (3) points a and b, it is mentioned "(a) For respect of the rights or reputations of others; (b) For the protection of national security or of public order (ordre public), or of public health or morals." 
immigrants and their descendants. It seems clear that the Council's terminology of hate speech in Europe's Committee of Ministers refers to cases of hate speech that often occur in European countries, especially anti-Semitism and xenophobia due to the influx of immigrants from Africa and the Middle East. In contrast to European countries, the issue of anti-Semitism and xenophobia in Indonesia is not as severe as the issue of religion, religious sect, belief, so the expression of organized hate in Indonesia is emphasized in statements that incite hatred towards individuals and/or groups on the basis of ethnicity, religion, religious sect, beliefs, race, class, color, ethnicity, gender, disability, and sexual orientation.

The hate speech is spreading easier thanks to the support of social media technology, and it is one of the biggest challenges of human civilization today. Social media-a collection of online communication channels dedicated to input content, messages, and information, interact, share content, and collaborate in the community (Marmo, 2007), is a very effective, easy, fast, and cheap platform in expressing and spreading hatred. From the data released by Hootsuite about the use of the internet and social media in Indonesia showed that 150 million active social media users in January 2019 rose 15\% compared to 2018. The data from the same source showed the average length of time Indonesian people access social media is 3 hours 26 minutes per day and it is ranked fourth in global after Philippine, Brazil, and Colombia. The popular social media platforms in Indonesia are Youtube (88\%), Whatsapp (83\%), Facebook (81\%), Instagram (80\%), Line (59\%), Twitter (52\%), Facebook Messenger (47\%).

The idea of multicultural education policy in Indonesia emerged in 1981 (Thomas, 1981) especially in response to the development of minority populations. However, more intensive discussions and studies only developed in the 1990s. Multiculturalism is often interpreted as an ideology that recognizes equality both individually and culturally. With this multiculturalism model, a community is seen as having a culture that is generally accepted in the society with the mosaic-style. The mosaic style embodies all cultures from smaller communities that shape the larger society. Each individual in the general cultural mosaic recognizes, accepts, upholds, and respects all cultures, including the cultures of small communities and minorities.

However, in reality, not every individual has such an attitude. There are many individuals who do not have "multicultural awareness". That fact is one of the basic arguments about the importance of multicultural education. Multicultural awareness itself includes three aspects, awareness of self, knowledge of differences, and interpersonal disposition toward diverse individuals (Dean, 2017). Awareness of self is the recognition and appreciation 
of one's cultural heritage and the influence on one's biases, values, beliefs and emotional responses to culturally different communities, including recognition of their limitations in dealing with multicultural problems (Pope, Reynolds, \& Mueller, 2019, p. 23). Knowledge of difference combines the recognition of diverse beliefs and values, knowledge of sociopolitical contexts and other people's cultural heritage, and familiarity with certain populations (Muldoon, 2016, p. 45). Furthermore, interpersonal disposition toward diverse individuals means the desire to be involved in building relationships, in which there are various perspectives, diversity of attitudes about inter-group friendship, and recognition of various sources of identity (Hopkins, 1997, p. 112).

Before the term of multicultural education was widely used, there were a number of terminologies that had been used in education: the education of the culturally different, ethnic studies, human relations, and education that is multicultural and social reconstructionist (Grant \& Sleeter, 1985). The terminology of education of the culturally different is targeted only at students from minority groups who aim to have equal access to educational institutions. Through this pattern, students from minority groups are encouraged to take education with curriculum, material, and language that is culturally relevant as a bridge to mainstream culture. Ethnic studies are targeted at all students from ethnic minorities only. The aim is to teach ethnic groups as different entities, and that each ethnicity plays an important role in people's lives. The terminology of human relations is targeted primarily at schools and multiracial classes. The aim is to prevent conflict among members of different ethnic groups, develop tolerance, and create positive self-development. And then, education that is a multicultural and social reconstructionist are generally targeted at all students. The aim is so that students can critically analyze why some groups in the community are oppressed, and so that they can take a more active and collective role in restructuring unequal relationships (Grant \& Sleeter, 1985, p. 100).

Among the various terminologies, multicultural education is the most popular terminology and is used today. In general, multicultural education is interpreted as an educational program that provides multiple learning resources for students (multiple learning environments) that fits their academic and social needs (Melnick, 2004). Multicultural education contains the idea that all students - regardless of sex, social class, and their ethnic, racial or cultural characteristics-must have equal opportunities to study in educational institutions (Banks, 2009). The main purpose of multicultural education is to change the structure of educational institutions so that all students of various races, sexes, ethnicities, languages and cultural groups have equal opportunities to achieve academic achievement in educational institutions (Banks, 2009, p. 
4). Moreover, multicultural education aims to help students understand the background of themselves and groups in society; respect and appreciate ethnic cultural and socio-historical diversity; solve over-ethnocentric and prejudiced attitudes; understand social, economic, psychological, and historical factors that cause ethnic polarization of ethnic inequality and alienation; enhance the ability to critically analyze socio-cultural problems through a vision of a better, fairer and more independent society; and develop wholesome identity to everyone. Multicultural education is directed at building awareness that differences in ability, in social backgrounds, in cultures, in "racial" or "ethnic" backgrounds, in gender, in sexual orientation, and in all forms of identity can help everyone develop a more comprehensive view about the world(Gorman, 1996, p. 69).

\section{Research Method}

This study with the descriptive method was based on the data obtained from 73 respondents of moderate Muslims (later called MMs) in West Java, Indonesia. The study was conducted from November 2018 to May 2019. The data were collected by direct interviews, via telephone, e-mail, and social media. The data is also obtained through text analysis in printed mass media and online social media. Moderate Muslims in this study are Muslims who have moderate views, attitudes, and behaviors in responding to various issues. Muhamadul Bakir Yaakub explained moderate in referring to the characteristics of individual and collective behaviors that are considered moderate, balanced, not being excessive or extreme (Yaakub, 2016, p. 67).

The considerations used by researchers to choose respondents are based on a number of criteria, which are Muslims who have moderate and not extreme views, attitudes, and behaviors, prioritize balance and tolerance, have commitment to peace, recognize diversity and pluralism, love virtue, invite (preach) with wisdom, recognize and accept the principles of democracy, and avoid hate. It must be admitted that these criteria can be very subjective, but, naturally, subjectivity in qualitative research is very difficult to avoid.

\section{Results and Discussion}

The views of moderate Muslims (MMs) in West Java, Indonesia, about freedom of expression, hate speech on social media, and multicultural education were elaborated and presented in the following four sub-discussions. 


\section{Freedom of Expression as a Basic Human Right}

Of the 73 people who are considered to represent MMs in the West Java region of Indonesia, all of them stated that freedom of expression is one of the human rights guaranteed by the constitution and legislation. According to MMs, freedom of expression is something that is inherent in every individual regardless of race, ethnicity, religion, gender, level of education, social status, and political affiliation. In their view, each individual citizen has the right to express or convey views, opinions, statements, judgments, and responses through various channels of communication and information in verbal, written, or video-audio, including through online social media.

None of the 73 respondents denied that freedom of expression is a human right protected by the constitution and law. They rejected the view that freedom of expression is part of Western values that are not in accordance with the social and cultural norms of the Indonesian people. For them, freedom of expression should be universal and not limited by space and time. Freedom of expression is not a monopoly of a particular culture or community, because it is inherent in every individual since birth.

They also disagreed with the view that freedom of expression is not in accordance with Islamic teachings. In their view, Islamic teachings provide a place and guarantee for everyone to express opinions, thoughts, and attitudes. Even one of the respondents, Fadlil Yani Ainusyamsi, argued that each country was obliged to guarantee the lives of its people to freely express their opinions. The state is not only obliged to protect and guarantee the security and safety of its people, but also must provide full guarantees of any dissent among its citizens. According to the religious leader who is also one of the lecturers of the Faculty of Adab and Humanity of Sunan Gunung Djati State Islamic University, every citizen should understand and realize that differences of opinion are part of the democratic process and the dynamics of society towards the aspired life. According to the lecturer, as the executor of constitutional life, the government may not monopolize opinions and deny the opinions of others. The government is required to be able to act as a facilitator of the dynamics and differences that occur in the community. The government must also be prepared to accept to disagree with the components of other nations, including receiving criticism as a manifestation of the implementation of democracy.

Hasan Bisri, one of the moderate Muslim academics who has expertise in the field of interpretation and Islamic law, connected this idea of freedom of expression with the concept of hurriyyah al-ra'y in Islamic fiqh. According to Hasan Bisri, this concept etymologically means freedom of opinion or freedom of speech. In the opinion of the lecturer of Sunan Gunung Djati Islamic State 
University, the term $r a^{\prime} y$ in Islamic teaching is usually divided into three types, praiseworthy, despicable, and doubtful. The praiseworthy ra'y or opinion is the $r a^{\prime} y$ described in the Qur'an, the Sunnah, the opinions of the Companions of the prophet, the $r a^{\prime} y$ which is the result of ijtihad, and $r a^{\prime} y$ achieved through the process of deliberation. The despicable one (al-ra'y al-mazmumah) is known in three types: bid'ah (destructive and misleading innovation), hawa (bad intention), and baghy (law violation). In the perspective of ushul al-figh, he said, $r a^{\prime} y$ is usually defined as an opinion on a matter which is not regulated in the Qur'an and the Sunnah. It is a thoughtfully considered opinion, achieved as a result of deep thought with the effort and hard work of a person. Thus, hurriyyah al-ra'y requires an intense, deep and sincere opinion and thought. Everyone may express their opinion as long as it does not violate the law with blasphemy and defamation and as long as it is based on logical, factual and responsible arguments.

Cucu Surahman, writer and lecturer at the Indonesian Education University (Universitas Pendidikan Indonesia/UPI) Bandung, viewed freedom of expression as one of the important instruments in a democratic country. Freedom of expression, according to Cucu Surahman, is in the spirit of democracy itself. For Cucu Surahman, freedom of expression is one of the instruments to realize the principle of check and balance in the order of a democratic society. Only by guaranteeing freedom of expression, a nation can create a balance between various socio-political forces through healthy opposition.

As one of the basic human rights, freedom of expression for citizens can be implemented for all types of expressions, ranging from opinions, views, arguments, impressions, statements, judgments, feelings, attitudes, interpretations, thoughts, responses, insights, estimates, etc. and include all objects and theme of expressions, starting from personal issues, friendships, social issues, economics, politics, religion, culture, international relations, etc. However, some respondents viewed that there were a number of issues which they considered as tidak pantas (inappropriate), tidak elok (not elegant), wagu (awkward), tidak patut (ill-suited ), tidak etis (unethical), tidak sopan (disrespectful), tidak pada tempatnya (out of place), and should not be expressed or discussed freely through social media. Sensitive issues that they thought should not be expressed freely on social media are about mental and physical disorders; disability or physical limitation, cognitive, mental, and emotional; one's religion or belief; ethnicity, race, skin color; the issue of lesbian, gay, bisexual and transgender/transsexual (LGBT). For respondents, statements on social media that contain elements of sensitive issues such as "he is a Christian", "his parents are Hindu", "he comes from a family of Syi'ah", 
"Ahmadiyah is not part of Islam", "he has small eyes, "he is an honest man, but unfortunately a Chinese", "tranny", "sissy", "handsome but gay", are unethical, not elegant, impolite, and out of place expressions.

However, MMs' view in West Java on the expression of these sensitive issues had more moral and ethical appeal. They tended to choose and use imperative phrases of moral and ethical guidance; not prohibitions, restrictions, or prohibitions that have legal connotations. These phrases are more suggestive in social media than to prohibit, curb, or even forbid. It can be interpreted that MMs' views of freedom of expression, including freedom of expression on social media, as something that is very basic and important, so that sensitive issues should not be prohibited from being discussed on social media.

\section{Restrictions of Freedom of Expression}

Although MMs in West Java viewed freedom of expression as one of the most basic human rights, they argue that freedom of expression in its implementation should not interfere with other people's human rights. That the implementation of freedom of expression must not disturb, reduce, negate or eliminate the rights of others.

Most MMs in West Java distinguished between freedom of expression and freedom of thought. For them, the implementation of freedom of expression will always have implications and intersect with other people because this freedom is related to opinions, views arguments, impressions, statements, judgments, feelings, attitudes, interpretations, responses, and views expressed or conveyed to others through various media channels, including social media. Meanwhile, freedom of thought does not have to always be conveyed or expressed to others. People can freely think without others knowing what they are thinking.

The majority of respondents interviewed viewed freedom of thought as having no restrictions and should not be restricted, except that "a Muslim should not think about the nature and existence of Allah.” (Al-Baihaqi, 1994) But it will be another problem if the thoughts are then conveyed and expressed to the public through social media. The majority of respondents not only saw the unnecessity to restrict freedom of thought, but even Islam also encouraged people to continue thinking about various phenomena in the universe. Islam in fact, according to them, makes freedom of thought one of the theological foundations. According to the respondents, freedom of thought and freedom of expression are two different things. The implementation of freedom of thought as one of the human rights generally does not interfere with the rights of other people. Thus, MMs in West Java saw the unnecessity to restrict freedom of thought. But with regard to freedom of expression, restrictions can be made so 
that freedom of expression does not disturb, hurt, intimidate or become a threat to other people or groups. In their view, freedom of expression must not be misused to spread hatred, create hostility, intimidate, scare, threaten, and terrorize other people or groups.

All MMs who were interviewed agreed with the importance of rules and law enforcement as instruments for restricting freedom of expression. Legal rules are needed in restricting freedom of expression so that restrictions on this freedom are not carried out arbitrarily and haphazardly. Cucu Surahman, one of the moderate Muslim academics who is also a lecturer at the Indonesian Education University in Bandung, saw the rule of law as the most effective instrument if restrictions on freedom of expression are to be carried out. The same view was also expressed by M. Anwar Syarifuddin, a lecturer at the Syarif Hidayatullah State Islamic University, from Cirebon; Syahirul Alim, an essayist, columnist, and works at the Syarif Hidayatullah UIN Language Center, Jakarta; Eva Saufana, educator from Kuningan Regency; Didin Zain, Lecturer at Sheikh Nurjati IAIN Cirebon. According to M. Anwar Syarifuddin, on the one hand, freedom of opinion cannot be carried out freely because a person's freedom is limited by the freedom of others, so there should be mutual respect for one another, especially for those with different views, so that the crossing of opinions that occur does not sacrifice the harmony.

Faqih Hasyim, a thinker and moderate Muslim figure, viewed freedom from two perspectives, positive freedom and negative freedom. According to him, positive freedom is the freedom that allows a person to grow and actualize himself optimally. In this positive freedom perspective, one can overcome the low dimension of himself in the form of physiological personal desire, one also can overcome the second dimension, which are things related to self-esteem and self-respect, in which, according to Faqih Hasyim, encourage someone to do hate speech. According to the Lecturer of Sheikh Nurjati IAIN Cirebon, one can actualize freedom positively if negative impulses in him/her are subjugated by the third dimension, namely rationality and great and noble ideas. Meanwhile, the negative freedom, according to him, is the freedom that occurs when humans can release themselves from anything that restrains them, especially the shackles of the doctrines of religion, tradition, ideology.

Some of MM's views - which allow restrictions on freedom of expression using laws and regulations - are relevant to a number of rules regarding freedom of expression, both at international and national levels. Article 19 The UDHR states that the application of restrictions on freedom of expression is solely to ensure respect for the rights and freedoms of others, as well as to fulfill the fair requirements that are in accordance with the values of decency, order and public welfare in a democratic society. This article also affirms that these 
restrictions can be carried out with the provisions stipulated in the law, must be in accordance with one of the objectives stated expressly in the text, and such restrictions are required. The ICCPR adds a condition that allows restrictions on this freedom, it is for reasons in protecting the rights or good name of others, health, and public decency.

Nationally, the restrictions on freedom of expression are regulated in the state constitution, where Article 28J paragraph (1) states that everyone is obliged to respect the human rights of others in orderly life of the society, nation, and state. Then Article 28J Paragraph (2) states that in exercising their rights and freedoms, every person must submit to the restrictions stipulated by law with the sole purpose of guaranteeing the recognition and respect for the rights and freedoms of others and to fulfill fair demands accordingly with consideration of morals, religious values, security, and public order in a democratic society. The restrictions on freedom of expression are also set forth in Law Number 39 of 1999 concerning Human Rights. In Article 70 it is affirmed that in exercising rights and obligations, each person must submit to the restrictions set by law with the aim of ensuring recognition and respect for the rights and freedoms of others and to fulfill just demands in accordance with moral, security, and public order in a democratic society. Then in Article 73 it is stated that the rights and freedoms set forth in this law can only be limited by and based on law, solely to guarantee the recognition and respect for human rights and basic freedoms of others, morality, public order and the interests of the nation.

In general, MMs in West Java viewed freedom of expression as the freedom that can be restricted or often referred to as derogable rights, not an absolute human right that cannot be restricted or non-derogable rights. This classification of human rights into derogable rights and non-derogable rights is based on theInternational Covenant on Civil and Political Rights. Nonderogable rights are rights that are absolute and the fulfillment must not be reduced by state parties, even if in an emergency. The rights included in this type are rights to life, rights to be free from torture, rights to be free from slavery, rights to be free from imprisonment for inability to fulfil a contractual obligation (debt), rights to be free from retroactive criminal law, Rights to recognition before the law, Rights in the freedom of thought, conscience and religion (Fitzpatrick, 1994, pp. 63-64). Meanwhile, rights in the type of derogable are rights that may be reduced or limited by the state. Rights and freedoms included in this type are the right to the freedom of peaceful assembly, the right to the freedom of association, including forming and becoming members of trade unions, the right to the freedom of expression, 
including the freedom to seek, receive and provide information and all kinds of ideas without paying attention to boundaries (either through oral or written).

For the respondents of this study, if freedom of expression is not restricted and mutated, the implementation of this right can interfere with and even threaten the human rights of other people or parties. Thus, restrictions on freedom of expression as one of the basic human rights can be carried out, but restrictions are only permitted by using laws that aim to guarantee recognition and respect for the rights and freedoms of others and to fulfill fair demands in accordance with moral considerations, security, and public order in a democratic society.

\section{The Views of Hate Speech on Social Media}

All MMs who were interviewed viewed the hate speech as a very serious problem faced by society today. They were concerned about the growing prevalence of hate speech on social media. Hate speech-as an incitement statement that fuels hatred towards individuals or groups on the basis of ethnicity, religion, belief, race, class, color, ethnicity, sex, disability, and sexual orientation-is a very problematic seriously faced by every community and nation in an era where all opinions, statements, arguments, attitudes, and judgments can be expressed through social media by everybody. That is why, Fadlil Yani Ainusyamsi, viewed the hate speech on social media as a serious challenge for the integration of the nation. If not handled properly, the spread of hate speech on social media can tear the social and cultural order of a nation. Hasan Bisri said that the spread of hate speech, especially on social media, was a threat to human civilization. Dadang Gani saw the strengthening of cases of hate speech on social media as one of the anomalies in communication and information technology that supports the rapid development of social media. Nasrulloh, one of the moderate Muslim figures from Cikarang-Bekasi, viewed the hate speech as a crime, especially if the hate speech is expressed in the form of insults, defamation, unpleasant acts, provocation, spreading false news, and all the above actions have a purpose or can have an impact on acts of discrimination, violence, killing, or social conflict as one form of criminal offense from hate speech.

According to Cucu Surahman, if hate speech is not anticipated and is not handled properly in accordance with statutory provisions, it can potentially lead to acts of discrimination, violence or even murder. Hate speech-which can be expressed through speeches on political campaign activities, banners, social media networks, public expressions or demonstrations, religious preach, printed and electronic mass media, and pamphlets— not only contrary to the 
laws and regulations, but also forbidden in religion, especially if it contains elements of incitement, humiliation, and abuse.

MMs in West Java believed in the aspect of law enforcement as a very important instrument to overcome the spread of hate speech, especially on social media. Legal action against perpetrators of hate speech is a very important solution to overcome the spread of hate speech. They also believed that enforcing the rule of law fairly, honestly, truthfully and openly can protect and fortify the public from the spread of hate speech on social media. Law enforcers are required to have firmness and courage to take action against every perpetrator who spreads hate speech on social media. According to the respondents, the courage and firmness of law enforcers are very important and urgently needed considering the case of the spread of hate speech on social media is very alarming.

However, Indra Gumilar Prasetia; Cucu Surahman; Eva Saufana; Dede Ahmad Ramdani; Nasrulloh; Ustadz Hasbi Habibi; Asep Deni Adnan Bumaeri; Badru Al-Khair; Ustadz Jajang Aisyul Muzakki; Amas M. Tamsis; Aep Kusnawan; Sugiri Permana; Irma Irawati; Didin Zain; Mursana; Ogi LesamaI; and M. Anwar Syarifuddin viewed the aspect of law enforcement as not the only solution to overcome the spread of hate speech on social media.

According to Indra Gumilar Prasetia, the legal approach is certainly less effective in overcoming the spread of hate speech on social media. It needs a more holistic approach, especially social, cultural and educational. According to Cucu Surahman, the effectiveness of legal prosecution on hate speech actors also needs to be supported by preventive efforts through social action and education. According to Badru Al-Khair, the legal approach can indeed be used in upholding the rules regarding the implementation of freedom of expression, but the legal aspect is not the only way. According to him, religion plays a very important role to fortify individuals from slander, lies, hatred, and hostility. Amas M. Tamsis considered that the legal approach alone is not real justice because according to him, not every thief deserves to be imprisoned. He also viewed religion, moral norms, and ethics as having an important role in overcoming the problem of spreading hate speech. Aep Kusnawan, also viewed law enforcement as inadequate, moreover the legal aspect often looked at something in black and white. In his view, a multi-perspective approach is needed, which according to him can be started by extracting the root of the problem, elaborating on the actual conditions, and considering the possible impacts and handling steps, so that the condition can be read as a whole through wisdom approach. According to Didin Zain, to overcome the spread of hate speech, the legal approach is not the only way. In the other hand, the legal approach can indeed provide a deterrent effect. However, for the long 
term, religious approaches, education, mental revolution, exemplary figures or other approaches need to be applied, so that the spread of hate speech is increasingly suppressed.

Irma Irawati, a novelist from Sukabumi, was also skeptical of a legal approach use as the only way in dealing with the problem hate speech. In fact, according to Irma Irawati, relying solely on legal aspects can worsen the problem, because the "braking" system is not based on conscience. She offered an approach to religion, ethics, and awareness for the consciences. For her, if a person is accustomed to expressing words by considering consciences first, perhaps the spread of hate speech can be suppressed and reduced.

The legal approach is indeed not effective in stemming the spread of hate speech on social media, according to M. Anwar Syarifuddin, especially when the implementation of the law uses double standards, On the one hand, the law is sharp to the opposing group, while on the other hand, the law is very blunt to the inside group. The same thing was also stated by Syahirul Alim, as long as the law is still a "tool" of power and to pressure the authorities, and is merely aimed at creating social stability, then the law is difficult to rely on in finding true justice, therefore, the law is also difficult to rely on to overcome the spread of hate speech on social media.

Relying on the legal aspects as the only approach to address the spread of hate speech on social media is seen as ineffective by almost all MMs in West Java who were interviewed because the spread of hate speech concerns a broad dimension and is triggered by complex variables. Sugiri Permana, a Religious Judge and Head of the Religious Court from West Java, tends to view the spread of hate speech not literally based on the writings or sayings of the perpetrators, but needs to be thoroughly and comprehensively examined, in the legal language, there needs to be reconstruction when someone spreads the hate speech. A person's expression in hate speech cannot be generalized, but needs to be examined the background of the conditions and atmosphere when someone spreads it so that it can be clearly known whether the statements that they express contain hate speech that meets the criminal element.

Freedom of expression and hate speech on social media according to most respondents is a dilemmatic condition. On the one hand, freedom of expression provides an open space for every citizen to express opinions, statements, arguments, attitudes, judgments, and responses in the public sphere, but on the other hand, freedom of expression can be seen as harassing the human rights of other people or parties. This dilemma, according to the respondents, can only be overcome through the establishment of clear rules and regulations that do not contain multiple interpretations, and are enforced fairly. The Indonesian government actually, according to the respondents, has 
had a number of laws and regulations governing freedom of expression and hate speech, among others, the Criminal Code (KUHP); Law Number 12 of 2005 on Ratification of the International Covenant on Civil and Political Rights; Law Number 39 of 1999 on Human Rights ; Law Number 40 of 1999 on Press, Law Number 32 of 2002 on Broadcasting, Law Number 11 of 2008 on Information and Electronic Transactions, and Law Number 33 of 2009 on Films; Law Number 19 of 2016 on the Amendment to Law Number 11 of 2008 concerning Information and Electronic Transactions; and Circular Letter of the Chief of the National Police Number SE/06/X/2015 concerning Handling of Hate Speech. From the aspect of rules, the actual freedom of expression and the spread of hate speech on social media are clear and complete. However, according to some respondents, there are problems related to enforcing the legislation. This is what M. Anwar Syarifuddin, referred to as sharp to the opponent but blunt to friends and inside groups. Or in the Syahirul Alim's opinion, the law is used as a tool of power and a tool to pressure the authorities and aims solely to create social stability.

Laws that are not open, transparent, honest, and fair, will only make citizens lose their trust in the law and the law enforcement agencies. This condition will make the hate speech to spread more. Some MMs viewed that law enforcement in Indonesia has fulfilled the principles of openness, justice and equality; but some of the other MMs were concerned about law enforcement efforts that were not maximized and seemed selective. This situation, among other things, causes the spread of hate speech on social media to occur frequently.

\section{Multicultural Education: Long-Term Alternative}

The dilemma between citizens' rights to express opinions and express themselves freely on one side, with the phenomenon of the spread of hate speech on social media on the other side, makes it difficult for social and political sciences experts to provide alternatives and solutions to their solutions. Some MMs in West Java who are also religious experts, legal experts, academics, social and political observers, hardly provide a solution that can balance the two dilemmatic problems.

When the rule of law and its enforcement efforts have not succeeded in realizing a balance between freedom of expression and the spread of hate speech, some MMs offered strategies for developing personality and human character. Irma Irawati offered character education as a long-term alternative. Sugiri Permana and Badru Al-Khair, offered religious education. Didin Zain, offered religious education, mental revolution, and exemplary figures. Aep Kusnawan and Indra Gumilar Prasetia offered a more holistic approach, they 
are cultural, social, and educational approaches. Cucu Surahman, offered educational, social, political and religious approaches. Syahirul Alim offered a more humanist approach, which is an approach that views reality as something that close with human relationships. Ustadz Hasbi Habibi put more emphasis on education which was able to internalize the prophetic values of the Prophet and build transcendence among Muslims.

Some of the other respondents relied on multicultural education. They offered multicultural education as the most sensible, grounded, systematic and long-term solution. Multicultural education is an alternative to build a mature democratic culture that respecting freedom of expression and controlling the spread of hate speech. It was offered by Fadlil Yani Ainuyamsi, Hasan Bisri, Dadang Gani, Muslihudin, Eva Saufana, Didin Jamaludin, and Nurzaman. In their view, multicultural education is believed to be able to stem the spread of hate speech based on a number of reasons. According to Dadang Gani, so far educational institutions have not been completely free from biases based on religion, ethnicity, race, sex, sexual orientation, age, physical or mental disability, and others. Through multicultural education, for him, educational institutions and communities can portray themselves as agents of multicultural awareness that are inclusive and free from all discriminatory policies, acts of violence, cultural-religious-ethnic bias, and various stereotypes. According to Fadlil Yani Ainusyamsi, the hate speech - which is nothing but an expression of degrading, harassing, hurting, berating, abusing, offending, insulting, and humiliating people or other group - often occurs because of the absence of multicultural awareness of the perpetrators and disseminators. In his view, multicultural education is believed to be able to equip students with the knowledge, insight, and awareness of living together in a multicultural society.

In Hasan Bisri's perspective, students are expected to gain experience through multicultural education where they can recognize and respect their own cultural heritage while acknowledging and respecting the culture of others. In addition, he also believed that multicultural education will be able to equip students with the ability to face and deal with problems that arise due to the diversity of cultural communities, including in dealing with the problem of the spread of hate speech. Muslihudin also viewed multicultural education in the long term as being able to equip students with the skills to deal with a tremendous wave of information, so that students are wiser in finding, filtering and disseminating messages and information on social media. In Eva Saufana's view, multicultural education has the power to fortify students from despicable character in the process of social interaction with different communities.

Furthermore, Didin Jamaludin believes that multicultural education can arouse the desire and passion to be involved in building relationships, in which 
there are various perspectives, diversity of attitudes, inter-group friendship, and recognition of various sources of identity. A relatively similar view was also expressed by Nurzaman. According to him, multicultural education can motivate students to be more involved in the process of interaction with people from various ethnic, religious, and cultural backgrounds. A relatively similar view was also expressed by Nurzaman. According to him, multicultural education can motivate students to be more involved in the process of interaction with people from various ethnic, religious, and cultural backgrounds

Multicultural education as an alternative in building a culture that is more mature, civilized, and has high ethical standards—so that it is not only able to uphold the right to freedom of expression, but also to be wise in using social media as a medium to search, share, and disseminating messages and information - seen as the most reasonable, most realistic, and as long-term solution. Multicultural education which is supported by rules and fair law enforcement is a strong capital in fortifying communities from the spread of hate speech.

MMs in West Java did not specifically offer curriculum ideas and multicultural education learning strategies in an effort to build a multicultural awareness society. However, when asked whether there is a need to add specific multicultural education subjects in the education curriculum, the majority of respondents answered that it is unnecessary. Multicultural education can be integrated into all subjects at all levels of education. Therefore, according to them, every educator must have multicultural competencies, namely qualifications, abilities, skills, and abilities to understand and overcome problems of ethnic, cultural and religious diversity. Educators are required to have multicultural knowledge, skills, attitudes, beliefs, and values as capital so that they can integrate multicultural education into the subjects they teach. In other words, the ability of educators to integrate multicultural education into subjects needs to be supported by multicultural knowledge, awareness, and skills.

In addition to having multicultural competencies, according to the respondents, educators also need to have the ability to develop active, innovative, creative, effective and enjoyable learning strategies so that multicultural education activities succeed in internalizing multicultural values to each student. Educators, in this case, are also required to have an open and flexible attitude in managing the diversity of students; have the ability to understand differences in student learning styles; are willing to accept differences in disciplines, backgrounds, races, and sexes; respect minority students; are willing to cooperate with various parties; are program and future- 
oriented; are sensitive to ethnic behavior of students; and are sensitive and tolerant to various differences and diversity of views, beliefs, and religions.

\section{Conclusion}

Upholding and respecting freedom of expression-as one of the basic human rights - is a noble character and a leading indicator of democracy. According to moderate Muslims in West Java, Indonesia, restrictions on the freedom of expression of citizens can be carried out to protect the human rights of other people or parties and be carried out based on clear rules of law. They also viewed that these human rights should not be misused to make and spread hate speech, including hate speech on social media. The spread of the hate speech on social media, according to the moderate Muslims, can be overcome by rules and law enforcement that meet the principles of justice and equality. However, the rules and law enforcement are not the only instruments to stem the spread of hate speech. Some approaches from the aspect of social, education, family, culture, and religion are also needed. One variable that is very important in developing a mature, civilized society with high ethical standards, and upholding freedom of expression without having to be involved in the hate speech is multicultural education. This multicultural education implementation can be integrated into every subject in educational institutions.

\section{REFERENCES}

Al-Baihaqi, A. B. A. ibn al-H. ibn 'Aliy ibn 'Abdullah ibn M. (1994). Sunan alShaghir al-Baihaqi. Makkah: Maktabah Dar al-Baz.

Banks, J. A. (2009). Multicultural Education: Characteristics and Goals. In J. A. Banks \& C. A. McGee (Eds.), Multicultural Education: Issues and Perspectives. New York: John Wiley and Sons.

Betz, H.-G. (2003). Radical Right-Wing Populism in Western Europe. London: The Macmillan Press Ltd.

Brison, S. (1998). The Autonomy Defence of Free Speech. Ethics, 17(2), 312339.

Dean, S. R. (2017). Development and Validation of a Multicultural Consciousness Instrument. Journal of Student Affairs Research and Practice. https://doi.org/10.1080/19496591.2017.1284670

Eatwell, R. (2000). The Rebirth of the 'Extreme Right' in Western Europe? Parliamentary Affairs, 53, 407-425.

Erjavec, K., \& Kovačič, M. P. (2012). You Don't Understand, This is a New 
War! Analysis of Hate Speech in News Web Sites' Comments. Mass Communication and Society, 15(6), 899-920. https://doi.org/10.1080/15205436.2011.619679

Fitzpatrick, J. (1994). Human Rights in Crisis: The International System for Protecting Rights During States of Emergency. Pennsylvania: University of Pennsylvania Press.

Frable, D. E. S. (1997). Gender, Racial, Ethnic, Sexual, and Class Identities. Annual Review of Psychology, 48, 139-162. https://doi.org/https://doi.org/10.1146/annurev.psych.48.1.139

Gorman, M. (1996). All Different, All Equal: A Sum of Experience. Germany: Council of Europe.

Grant, C. A., \& Sleeter, C. E. (1985). The Literature on Multicultural Education: Review and Analysis. Educational Review, 37(2), 97-118. http://dx.doi.org/10.1080/0013191850370202

Hauptfleisch, D. C. (1993). Racist Language in Society and in Dictionaries: A Pragmatic Perspective. Lexikos, 3, 83-144.

Hopkins, W. E. (1997). Ethical Dimensions of Diversity. London: Sage.

Husin, B. R., Febriyani, M., \& Sunarto. (2018). Analisis Faktor Penyebab Pelaku Melakukan Ujaran Kebencian (Hate Speech) dalam Media Sosial. Jurnal Poenale, 6(3).

Husni. (2016). The Challenges of Religious Education in Indonesia and the Future Perspectives. Religious Studies: An International Journal, 4(2).

Retrieved from https://fssh-journal.org/index.php/jrs/article/view/12

Ignazi, P. (2009). Extreme Right Parties in Western Europe. Oxford: Oxford University Press.

Inglehart, R. F., \& Norris, P. (2016). Trump, Brexit, and the Rise of Populism: Economic Have-Nots and Cultural Backlash. Harvard: Harvard Kennedy School.

International NGO Forum on Indonesian Development (INFID). (2019). Urgensi dan Strategi Efektif Pencegahan Ekstremisme di Indonesia. Retrieved from https://www.infid.org/wpcontent/uploads/2018/12/Buku-Ringkasan-Urgensi-dan-Strategi-EfektifPencegahan-Ekstremisme-di-Indonesia-Rev2019.pdf

Kehrberg, J. E. (2007). Public Opinion on Immigration in Western Europe: Economics, Tolerance, and Exposure. Comparative European Politics, 5, 264-261.

Langton, R. (1993). Speech Acts and Unspeakable Acts. Philosophy and Public Affairs, 22(4), 293-330.

Marmo, R. (2007). Competitive Analysis Based on Social Media Mining. In M. Khosrow-Pour (Ed.), Handbook of Research on Global Enterprise 
Operations and Opportunities. Pennsylvania: IGI Global.

Mathew, B., Dutt, R., Goyal, P., \& Mukherjee, A. (2018). Spread of Hate Speech in Online Social Media. CoRR. https://doi.org/abs/1812.01693

Matteo, B. (2017). Religion, Hate Speech and Non-Domination. Sage Journal, 17(2), 259-274. https://doi.org/10.1177\%2F1468796817692626

Melnick, S. L. (2004). Multiculturalism: One View from the United State of America. In M. Ben-Peretz, S. Brown, \& B. Moon (Eds.), Routledge International Companion to Education. London: Routledge.

Mesa, R. M. (2016). Hate-Speech in the Romanian Online Media. Journal of Media Reseach, 9(3), 55-77.

Mill, J. S. (1865). On Liberty. Oxford: Longmans, Green, and Company.

Muldoon, R. (2016). Social Contract Theory for a Diverse World: Beyond Tolerance. London: Routledge.

Pember, D. R. (2001). Mass Media Law. New York: The McGraw-Hill Companies, Inc.

Pope, R. L., Reynolds, A. L., \& Mueller, J. A. (2019). Multicultural Competence in Student Affairs: Advancing Social Justice and Inclusion. San Francisco: John Wiley \& Sons.

Shaw, L. (2011). Hate Speech in Cyberspace: Bitterness without Boundaries. Notre Dame Journal of Law, Ethics and Public, 25(1), 279-304.

Svensson-McCarthy, A.-L. (1998). The International Law of Human Rights and States of Exception: With Special Reference to the Travaux Preparatoires and the Case-law of the International Monitoring Organs. London: Martinus Nijhoff Publishers.

The Wahid Foundation. (2017). Laporan Tahunan Kebebasan Beragama/Berkeyakinan di Indonesia 2017. Jakarta: The Wahid Institute.

The Wahid Institute. (2010). Laporan Tahunan Kebebasan Beragama/Berkeyakinan dan Intoleransi di Indonesia 2010. Jakarta: The Wahid Institute.

The Wahid Institute. (2011). Laporan Tahunan Kebebasan Beragama/Berkeyakinan dan Intoleransi di Indonesia 2011. Jakarta: The Wahid Institute.

The Wahid Institute. (2012). Laporan Tahunan Kebebasan Beragama/Berkeyakinan dan Intoleransi di Indonesia 2012. Jakarta: The Wahid Institute.

The Wahid Institute. (2013). Laporan Tahunan Kebebasan Beragama/Berkeyakinan dan Intoleransi di Indonesia 2013. Jakarta: The Wahid Institute.

The Wahid Institute. (2014). Laporan Tahunan Kebebasan Beragama/Berkeyakinan dan Intoleransi di Indonesia 2014. Jakarta: The 
Wahid Institute.

The Wahid Institute. (2015). Laporan Tahunan Kebebasan Beragama/Berkeyakinan dan Intoleransi di Indonesia 2015. Jakarta: The Wahid Institute.

The Wahid Institute. (2016). Laporan Tahunan Kebebasan Beragama/Berkeyakinan dan Intoleransi di Indonesia 2016. Jakarta: The Wahid Institute.

Thomas, R. M. (1981). Indonesia's Cultural Pluralism and Education. Educational Research Quarterly, 6.

Weissbrodt, D. S., \& de la Vega, C. (2007). No TitleInternational Human Rights Law: An Introduction. Philadelphia: University of Pennsylvania Press.

Wolfson, N. (1997). Hate Speech, Sex Speech, Free Speech. Westport, CT: Praeger Publishers.

Woodward, M. et al. (2014). The Islamic Defenders Front: Demonization, Violence and the State in Indonesia. Cont Islam, 8, 153-171. https://doi.org/10.1007/s11562-013-0288-1

Yaakub, M. B. (2016). A Textual Analysis for the Term 'Wasatiyyah' (Islamic Moderation) in Selected Quranic Verses and Prophetic Tradition. Journal of Education and Social Sciences, 5(October). 
